\title{
Produksi Telur dan Kualitas Telur Ayam IPB D-1 G7 serta Pendugaan Nilai Ripitabilitasnya
}

\author{
Egg Production and Egg Quality IPB D-1 Chicken G7 and Repeatabilty Estimation
}

\author{
R. Habiburahman*, S. Darwati, C. Sumantri, \& Rukmiasih \\ Departemen Ilmu Produksi dan Teknologi Peternakan, Fakultas Peternakan, Institut Pertanian Bogor \\ Jl. Agatis, Kampus IPB Darmaga Bogor 16680, Indonesia \\ *Email koresponden author: restuhabiburahman@gmail.com \\ (Received 19-04-2020; Revised 31-05-2020; Accepted 12-06-2020)
}

\begin{abstract}
IPB-D1 is a chicken cross between male F1 PS (PelungxSentul) with F1 female (Kampung $x$ parent stock cobb). The establishment of chicken IPB-D1 aims to produce commercial meat type local chicken with semi-intensive maintenance management. The aim of this research to observe study assesses the performance of egg production and the quality of IPB D-1 chicken eggs and estimates the value of repeatability of production and haugh units of IPB D-1 chicken eggs. The chicken was observed as many as 30 hens IPB D-1 G7 aged 24-36 weeks and eggs as many as 288 eggs. The production and egg quality data were analyzed descriptively and the repeatability values were analyzed with Anova. Egg weight 40 g, Haugh unit value 87 (Very good), egg production $49.22 \%$. The repeatability value of egg production is 0.2 (Moderate) and the repeatability value of the haugh unit is 0.31 (Medium). IPB D-1 Chicken has the potential to be a good dual-purpose chicken.
\end{abstract}

Keywords: IPB D-1 Chicken, Production, Ripitability

\begin{abstract}
ABSTRAK
IPB-D1 adalah ayam persilangan antara jantan F1 (PelungxSentul) dengan betina F1 (Kampung $x$ parent stock cobb). Pembentukan ayam IPB-D1 bertujuan untuk memproduksi ayam lokal jenis pedaging komersial dengan manajemen pemeliharaan semi intensif. Penelitian ini bertujuan mengkaji performa produksi telur dan kualitas telur ayam IPB D-1 serta mengestimasi nilai ripitabilitas produksi dan haugh unit telur ayam IPB D-1. Ternak yang diamati sebanyak 30 ekor betina IPB D-1 G7 umur 24-36 Minggu dan telur sebanyak 288 butir telur. Data produksi dan kualitas telur dianalisis deskriptif dan dianalisis nilai ripitabilitasnya dengan ANOVA. Bobot telur 40 g, Nilai Haugh unit 87 (Sangat baik), produksi telur $49.22 \%$. Nilai ripitabilitas produksi telur 0.2 (sedang) dan nilai ripitabilitas haugh unit 0.31(Sedang). Ayam IPB D-1 memilki potensi sebagai ayam dwiguna yang baik.
\end{abstract}

Kata kunci : Ayam IPB D-1, produksi, ripitabilitas

\section{PENDAHULUAN}

Telur merupakan salah satu protein hewani yang terjangkau masyarakat. Konsumsi telur terus meningkat ini dapat dilihat dari kenaikan konsumsi telur perkapita dan produksi telur secara umur di Indonesia. Menurut BPS (2019) konsumsi telur perkapita perminggu sebanyak 2.12 pada tahun 2017 dan meningkat menjadi 2.15 setiap minggunya. Peningkatan konsumsi telur ini harus diiringi peningkatan produksi. Salah satu untuk meningkatan produksi telur yaitu dengan meningkatkan produktivitas ternak tersebut.
Ayam hasil persilangan ayam lokal dengan ayam ras pedaging meningkatkan produktivitas ayam lokal yaitu bobot badan, ukuran tubuh, dan produksi telur. Salah satu ayam lokal yang disilangkan dengan ayam ras pedaging adalah ayam IPB D-1. Ayam IPB D-1 merupakan silangan 3 rumpun ayam yaitu ayam kampung, ayam pelung, dan ayam sentul dengan ayam ras pedaging. Ayam IPB D-1 walaupun ayam lokal yang ditujukan untuk ayam memilki pertumbuhan yang baik disamping itu memilki potensi produksi telur dari sumbangan $25 \%$ genetik ayam ras.

Ayam IPB D-1 juga menghasilkan telur yang cukup produktif. Telur ayam bernilai gizi tinggi, namun mudah 
rusak, disamping itu telur ayam lokal memilki potensi yang tinggi di kota maupun dipedesaan. Telur ayam lokal dianggap memiliki rasa lebih enak dibandingkan dengan telur ayam ras. Harga jual yang tinggi menjadi salah satu faktor telur ayam lokal tidak sepopuler ayam ras. Oleh karena itu perlunya penelitian kualitas dan produksi telur ayam lokal untuk mengetahui potensi produksi dan kualitas telur ayam lokal indonesia untuk bersaing dengan telur ayam ras

Ripitabilitas merupakan salah satu parameter genetik untuk mengetahui daya ulang suatu sifat yang dimiliki individu selama individu tersebut hidup (Darwati et al. 2019). Nilai ripitabilitas menurut Noor (2008) antara 0-1. Nilai tersebut menggambarkan kemampuan ternak untuk mengulangi produksi sekarang di masa yang akan datang.

Tujuan penelitian ini adalah mengkaji perfoma produksi dan kualitas telur ayam indukan serta keturunannya. Mengestimasi nilai ripitabilitas produksi telur dan kualitas telur ayam IPB D-1 G7. Data produksi telur menjadi indikator untuk melihat effisiensi ayam lokal petelur. Kualitas telur dapat dilihat dari interior dan eksterior. indeks putih telur, indeks kuning telur, indeks haugh, dan daya buih putih telur merupakan uji kualitas telur secara interior. Pada penelitian ini untuk mengukur kualitas telur dengan mencari nilai haugh unit $(\mathrm{HU})$.

\section{MATERI DAN METODE}

\section{Waktu dan Lokasi Penelitian}

Penelitian dilaksanakan pada bulan Juli sampai Desember 2019. Lokasi penelitian di Laboratorium Lapang Pemuliaan dan Genetika Ternak, Fakultas Peternakan, Institut Pertanian Bogor.

\section{Alat dan Bahan}

Peralatan yang digunakan pada penelitian ini adalah 40 kandang individu berukuran $35 \mathrm{~cm} \times 29 \mathrm{~cm} \times 35 \mathrm{~cm}$. Alat lain yang digunakan untuk pemeliharaan ayam adalah tempat pakan, tempat minum, ember, gayung, dan egg tray. Pengambilan data yang dilakukan dalam penelitian ini menggunakan alat berupa timbangan digital dengan ketelitian $0.1 \mathrm{~g}$ untuk bobot telur, kuning telur, putih telur, dan kerabang. Jangka sorong untuk lebar dan panjang telur. Meja kaca sebagai wadah pengukuran. Mikrometer sekrup untuk mengukur tebal kerabang. Roche Yolk Colour Fan untuk mengukur warna kuning telur. Alat lain yang dibutuhkan yaitu tabulasi data produksi telur dan alat tulis.

Bahan yang digunakan pada penelitian ini adalah ayam betina hasil persilangan pelung-sentul-kampungras pedaging generasi ke-7 (IPB D-1 G7) 32 betina umur 24 minggu yang telah siap bertelur dan 288 telur. Bahan lain yang dibutuhkan adalah pakan komersial untuk ayam petelur, dedak padi, air, vita chick, sekam, vaksin ND, tetra chlore, dan formalin.

\section{Prosedur}

\section{Persilangan}

Ayam IPB D-1 Generasi ke-6 disilangkan interse kembali untuk memperoleh IPB D-1 G7. Ilustrasi persilangan dapat dilihat pada Gambar 1.

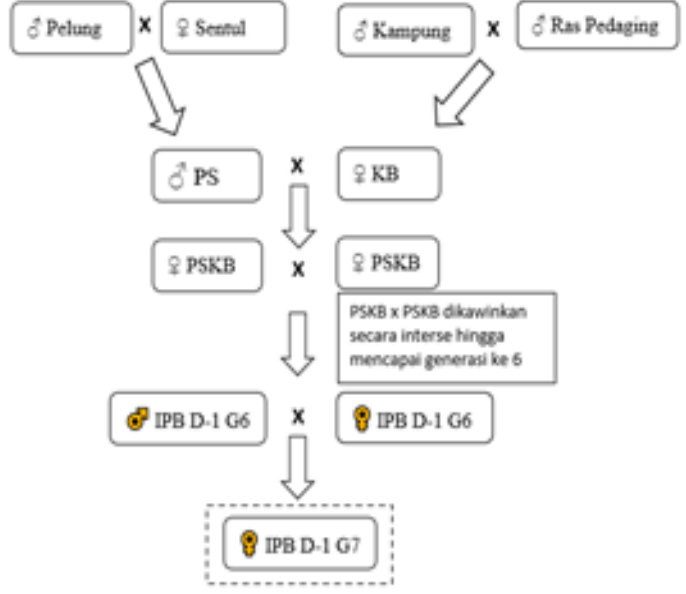

Gambar 1. Ilustrasi persilangan ayam yang dikaji dan bagian (---) diamati pada penelitian ini.

\section{Pemberian Pakan dan Air Minum}

Pakan diberikan $100 \mathrm{~g}$ perhari dan air minum diberikan ad libitum. Pemberian pakan dilakukan sebanyak 2 kali sehari yaitu pagi dan sore hari. Pakan komersial untuk petelur sebanyak $60 \%$ dengan campuran dedak $40 \%$. Kandungan nutrisi pakan yang digunakan dapat dilihat pada Tabel 1.

Tabel 1. Kandungan Nutrisi Pakan

\begin{tabular}{lc}
\hline & Pakan Campuran \\
\hline Kadar air & 11.96 \\
Protein & 14.12 \\
Lemak kasar & 5.18 \\
Serat Kasar & 10.56 \\
Abu & 12.32 \\
\hline
\end{tabular}

\section{Pengumpulan Telur}

Telur ayam yang akan diuji kualitas telur dikoleksi pada pagi dan sore hari. Pada malam hari dilakukan pengukuran kualitas telur untuk menjaga kesegaran telur. Telur yang digunakan untuk uji kualitas merupakan sample telur sebanyak 9 butir yang dikoleksi sebanyak 3 kali pada periode kesatu, kedua, dan ketiga. Produksi telur berdasarkan data pencatatan produksi. Data Produksi telur per ekor dikoleksi dari 30 ekor ayam betina.per per hari. Data produksi yang diperoleh untuk menduga produksi dan parameter genetik produksi telur.

\section{Kualitas Telur}

Pengamatan kualitas telur ayam IPB D-1 G7 setiap indukan diambil 9 butir telur sebagai sampel. Data yang diambil untuk mengevaluasi kualitas telur pada penelitian ini adalah bobot telur, bobot kuning telur, bobot putih telur, bobot kerabang basah, haugh unit, warna kuning telur, dan tebal kerabang telur. Warna kuning telur diamati dengan alat pembantu Roche Yolk Colour Fan dengan skor 1-15 dengan 15 macam warna. Menurut Stadelman \& Coteriil (1977) menjelaskan bahwa HU dapat dihitung dengan rumus :

$$
\mathrm{HU}=100 \log (\mathrm{H}+7.57-1.7 \mathrm{~W} 0.37)
$$


Keterangan :

$\mathrm{HU}=$ Haugh unit

$\mathrm{H}=$ tinggi putih telur kental $(\mathrm{mm})$

$\mathrm{W}=$ bobot telur $(\mathrm{g})$

\section{Analisis Data}

\section{Produksi Telur}

Data dianalisis secara deskriptif dengan menyajikan rataan $(\overline{\mathrm{X}})$, simpangan baku $(\mathrm{SD})$, dan koefisien keragaman (KK).

\section{Nilai Ripitabilitas}

Nilai ripitabilitas merupakan nilai yang menggambarkan nilai ternak untuk mengulangi performanya di masa akan datang. Menurut Noor (2008) Nilai ripitabilitas berkisar $0-1$. Nilai ripitabilitas pada penelitian ini menggunakan data produksi telur yang didapatkan selama 3 bulan dan nilai haugh unit yang telah diambil. Data produksi telur yang didapatkan dibagi menjadi produksi setiap bulan sehingga didapatkan data produksi telur 3 kali pengulangan. Nilai ripitabilitas dapat diduga menggunakan hasil dari analisis ragam (Becker 1985) yang dapat dilihat pada Tabel 2 sehingga didapatkan nilai ripitabilitas produksi telur dan haugh unit ayam IPB D-1 G7.

Tabel 2. Daftar sidik ragam

\begin{tabular}{lcccc}
\hline Sumber Keragaman & $\mathrm{Db}$ & $\mathrm{SS}$ & $\mathrm{MS}$ & $\mathrm{EMS}$ \\
\hline Antar Individu & $\mathrm{N}-1$ & $\mathrm{SSw}$ & $\mathrm{MSw}$ & $\delta_{\mathrm{e}}{ }^{2}+\mathrm{k} \delta_{\mathrm{w}}{ }^{2}$ \\
Antar Pengukuran dalam & $\mathrm{m}-\mathrm{N}$ & $\mathrm{Sse}$ & $\mathrm{Mse}$ & $\delta_{\mathrm{e}}{ }^{2}$ \\
Individu & & & &
\end{tabular}

Sumber : Becker (1985)

$\mathrm{N}=$ Jumlah individu

$\mathrm{m}=$ Jumlah total pengukuran

$\mathrm{k}=1 /(\mathrm{m}-1)\left(\mathrm{m}-\left(\sum \mathrm{m}_{\mathrm{k}}^{2}\right) / \mathrm{m}\right)$

$\delta_{\mathrm{e}}^{2}=\mathrm{MSe}$

$\delta_{\mathrm{w}}{ }^{2}=(\mathrm{Ms}(\mathrm{w}+\mathrm{Mse})) / \mathrm{k}$

$\mathrm{R}^{\mathrm{w}}=\delta_{\mathrm{e}}^{2}+\mathrm{k} \delta_{\mathrm{w}}^{2}$

$\mathrm{SE}(\mathrm{R}) \stackrel{\mathrm{e}}{=} \sqrt{ }\left(\left(2^{\mathrm{w}}(1-\mathrm{R})^{2}[1+(\mathrm{k}-1) \mathrm{R}]\right) /(\mathrm{k}(\mathrm{k}-1)(\mathrm{N}-1))\right)$

\section{Peubah}

Peubah yang diamati adalah produksi telur dan kualitas telur.

1. Produksi telur $=$ produksi telur yang dihasilkan ayam dalam 1 periode

2. Haugh Unit $=$ mengukur tinggi putih telur $(\mathrm{H})$ dan bobot telur (g) dan dimasukan kedalam rumus HU menurut Stadelman \& Coteriil (1977).

3. Index telur $=$ mengukur panjang telur, lebar telur, tinggi putih telur, lebar kuning telur, tebal kerabang, dan berat kerabang.

\section{HASIL DAN PEMBAHASAN}

\section{Kualitas telur}

Telur konsumsi yang baik adalah ketika telur baru keluar dari ayam yang belum banyak mengalami penurunan kualitas telur. Salah satu hal yang dapat dijadikan acuan telur masih dalam kondisi bagus salah satunya Haugh unit telur. Adapun parameter indeks dan kualitas telur ayam IPB D-1 G7 dari 288 telur dapat dilihat pada Tabel 3.

Dari informasi Tabel 3 dapat didapatkan informasi bahwa karakteristik telur ayam IPB D-1. Bobot telur 40.54 g, tinggi putih telur $6.6 \mathrm{~mm}$, panjang telur $51.05 \mathrm{~mm}$, lebar telur $38.01 \mathrm{~mm}$, bobot putih $23.00 \mathrm{~g}$, bobot kuning $12.29 \mathrm{~g}$, warna kuning 7, berat kerabang $4.58 \mathrm{~g}$, tebal kerabang 2.9 mm, nilai HU 87.45.

Tabel 3. Rataan $\pm \operatorname{sd}(\mathrm{KK})$ performa produksi dan kualitas telur ayam IPB D-1 G7

\begin{tabular}{ll}
\hline Parameter & \multicolumn{1}{c}{ Rata-rata } \\
\hline Bobot $(\mathrm{g})$ & $40.54 \pm 4.49(20.25)$ \\
Tinggi Putih $(\mathrm{mm})$ & $66 \pm 0.97(0.95)$ \\
Panjang $(\mathrm{mm})$ & $51.05 \pm 2.70(7.29)$ \\
Lebar $(\mathrm{mm})$ & $38.02 \pm 3.05(9.33)$ \\
Bobot Putih $(\mathrm{g})$ & $23.00 \pm 2.74(2.77$ \\
Warna Kuning & $7.16 \pm 1.26(1.60)$ \\
Bobot Kuning $(\mathrm{g})$ & $12.29 \pm 1.66(2.77)$ \\
Berat Kerabang $(\mathrm{g})$ & $4.58 \pm 0.06(0.94$ \\
Tebal Kerabang $(\mathrm{mm})$ & $0.3 \pm 1.74(3.02)$ \\
Nilai HU & $87.45 \pm 5.32(28.35)$ \\
\hline
\end{tabular}

Berat telur ayam IPB D-1 G7 masih tergolong seperti ayam kampung. Berat telurayam kampung pada penelitian Hartono (2014) sebesar 38-42 g. SNI telur ayam konsumsi (2008) mengkelompokan menjadi tiga jenis berdasarkan bobotnya yaitu bobot telur $<50$ g (kecil), bobot telur 50$60 \mathrm{~g}$ (sedang), bobot telur $>60 \mathrm{~g}$ (besar). Berdasarkan pengkelompokan SNI telur ayam IPB D-1 G7 tergolong kecil. Tebal kerabang ayam IPB D-1 G7 tergolong tipis 0.3 mm keuntungan dari kerabang tipis ini memudahkan ayam saat proses pipping saat menetas.

Kualitas telur merupakan salah satu untuk menentukan telur itu baik dan buruknya. Dalam hal ini parameter yang digunakan dalam menentukan kualitas telur yaitu haugh unit. Nilai haugh unit lebih dari 72 dikategorikan sebagai telur berkualitas AA, nilai haugh unit 60-72 sebagai telur berkualitas A, nilai haugh 10 unit 3160 sebagai telur berkualitas B dan nilai haugh unit kurang dari 31 dikategorikan sebagai telur berkualitas C (Mountney 1976). Nilai haugh unit ayam IPB D-1 G7 yang diperoleh sebesar 87.45 sehingga dapat dikatakan kualitas telur ayam IPB D-1 G7 baik. Tingginya nilai haugh unit dikarekan telur diukur maksimal 1 hari setelah pengumpulan telur sehingga telur masih dalam keadaan segar. Peniilaian kualitas telur sangat penting untuk mengetahui kualitas telur tersebut sehingga masyaratkan mengetahui secara umum telur yang mereka konsumsi yaitu telur yang memilki kualitas yang baik.

Kerabang telur ayam IPB D-1 G-7 diperoleh ratarata $0.3 \mathrm{~mm}$ lebih tipis dibandingkan dengan penelitian Widyantara et al. (2017) tebal kerabang ayam kampung yang diperoleh $0.32-0.35$. Beberapa faktor memengaruhi tebal kerabang, yaitu umur, faktor genetik, kesehatan, lingkungan, dan pakan. Kerabang yang tipis relatif berpori 
lebih banyak dan besar, sehingga mempercepat turunnya kualitas telur akibat penguapan dan pembusukan lebih cepat (Widyantara et al. 2017). Proses penguapan yang lebih cepat ini beresiko membuat DOC yang dihasilkan akan lebih kecil karena susut tetas pada saat penetasan telur. Kerabang yang tipis juga dikhawatirkan jika menjadi telur konsumsi akan mudah retak/pecah pada saat proses distribusi.

Nilai koefisien keragaman sampai saat ini tidak ada yang baku, namun menurut Menurut Mattjik \& Sumertajaya (2000), koefisien keragaman 20-25\% masih termasuk homogen. Bobot, tinggi putih, lebar, bobot putih, warna kuning, bobot kuning, bobot kerabang, tebal kerabang, dan panjang telur termasuk seragam. Haugh unit tidak seragam. Tingginya keragaman dapat diatasi dengan melakukan seleksi sehingga didapatkan keseragaman yang diinginkan.

Tabel 4. Rataan $\pm \mathrm{sd}(\mathrm{KK})$ produksi telur ayam IPB D-1 G7

\begin{tabular}{lcccc}
\hline & \multicolumn{3}{c}{ Bulan Ke- } & Total \\
\cline { 2 - 4 } & 1 & 2 & 3 & \\
\hline Jumlah & $17.07 \pm 3.19$ & $15.00 \pm 4.53$ & $12.23 \pm 4.59$ & $44.3 \pm 9.39$ \\
Telur* & $(10.20)$ & $(20.55)$ & $(21.08)$ & $(88.08)$ \\
Persen & 56.9 & 50 & 40.7 & 49.2 \\
$(\%)$ & & & & \\
\hline
\end{tabular}

\section{Produksi Telur}

Produksi telur ayam lokal relatif rendah salah satunya ayam kampung yaitu sekitar $41.37 \%$ menurut Creswell \& Gunawan (1982). Rendahnya produksi telur ayam lokal dikarenakan faktor genetik dari ayam lokal dan konsumsi pakan ayam. Pada ayam IPB D-1 G7 Produksi telur mencapai $49.22 \%$ lebih baik dibandingkan literatur. Peningkatan produksi telur ayam IPB D-1 G7 disebabkan oleh persentase genetik ayam ras sebanyak $25 \%$. Sumbangan $25 \%$ genetik ayam ras inilah yang menyebabkan peningkatan produksi telur ayam IPB D-1 G7 dibandingkan ayam lokal pada umumnya.

Koefisien keragaman produksi telur ayam IPB D-1 G7 masih beragam. Produksi telur ayam IPB D-1 G7 jika dilihat perbulannya masih seragam dengan nilai koefisien keragaman 10-21, akan tetapi jika dilihat dari total produksi telur nilai koefisien keragaman yang diperoleh cukup tinggi yaitu 88.08. Tingginya nilai koefisien keragaman dikarenakan masih beragamnya produksi telur setiap individu ayam IPB D-1 G7. Produksi telur ayam IPB D-1 G7 selama 90 hari yang diteliti paling rendah 24 telur dan paling tinggi 64 telur, ini yang menyebabkan tingginya nilai koefisien keragaman. Rendahnya produksi telur pada salah satu individu dikarenakan keluarnya sifat mengeram pada ternak yang kurang diharapkan untuk ayam jenis petelur. Tingginya produksi telur pada ayam IPB D-1 G7 dikarenakan faktor genetik ayam ras.

Peningkatan produktivitas telur penting untuk meningkatkan effisiensi produksi dikarenakan jumlah telur yang dihasilkan tinggi akan mengurangi jumlah pakan yang dibutuhkan. Dalam penelitian ini diharapkan didapatkan data dasar untuk menentukan seleksi keturunan ayam yang memilki produksi telur yang baik. Sehingga diharapkan ayam IPB D-1 kedepannya memilki produksi telur yang tinggi serta pertumbuhan sampai bobot potong yang tinggi.

\section{Ripitabilitas}

Besarnya nilai ripitabilitas berkisar antara 0-1 (Noor 2008). Semakin tinggi nilai ripitabilitas dapat diartikan semakin besar ternak tersebut akan mengulangi produksinya di masa akan datang. Anova nilai ripitabilitas produksi telur ayam IPB D-1 G7 dapat dilihat pada Tabel 5.

Ripitabilitas produksi telur ayam IPB D-1 G7 yang diperoleh berdasarkan sidik ragam yaitu 0.2 . Hal tersebut berarti bahwa keragaman daya ulang produksi telur ayam IPB D-1 G7 20\% dipengaruhi oleh ragam genotip dan lingkungan yang permanen. $80 \%$ lainnya keragaman dipengaruhi oleh ragam gen lainnya dan ragam gen yang disebabkan oleh lingkungan. Hal ini dikarenakan produksi telur termasuk sifat kuantitatif yang dikontrol oleh gen minor sehingga ekspresi gen tersebut dikontrol oleh banyak pasang gen dan ekspresinya dipengaruhi oleh lingkungan, seperti cuaca, manajamen, dan pakan.

Ripitabilitas haugh unit telur ayam IPB D-1 G7 berdasarkan data yang diperoleh didapatkan nilai ripitabilitas produksi telur adalah 0.31 . Hal tersebut berarti bahwa keragaman daya ulang produksi telur ayam IPB D-1 G7 31\% dipengaruhi oleh ragam genotip dan lingkungan yang permanen. 69\% lainnya keragaman dipengaruhi oleh ragam gen lainnya dan ragam gen yang disebabkan oleh lingkungan. Menurut Lasley (1987), perbedaan nilai heritabilitas suatu sifat dapat disebabkan oleh perbedaan jumlah pengamatan, jenis ternak, waktu, lingkungan serta metode pendugaan yang digunakan.

Tabel 5. Anova nilai ripitabilitas produksi telur ayam IPB D-1 G7

\begin{tabular}{lcccccc}
\hline & $\mathrm{db}$ & JK & KT & Ragam w & Ragam e & Nilai Ripitabilitas \\
\hline JK Antar Individu & 29 & 851,43 & 29,35 & 4,20 & 16,74 & 0,20 \\
Galat & 60 & 1004,66 & 16,74 & & & \\
Total & 89 & 1856,1 & & & & \\
\hline
\end{tabular}

Tabel 6. Anova nilai ripitabilitas haugh unit telur ayam IPB D-1 G7

\begin{tabular}{lcccccc}
\hline & $\mathrm{db}$ & $\mathrm{JK}$ & $\mathrm{KT}$ & Ragam w & Ragam e & Nilai Ripitabilitas \\
\hline JK Antar individu & 31 & 1807,48 & 58,31 & 11,18 & 24,76 & 0,31 \\
Galat & 256 & 6338,53 & 24,76 & & & \\
Total & 287 & 8146,01 & & & & \\
\hline
\end{tabular}




\section{KESIMPULAN}

Produksi telur ayam IPB D-1 G7 49.22\%. Nilai ripitabilitas produksi telur tergolong sedang. Ripitabilitas haugh unit tegolong sedang. Haugh unit telur ayam IPB D-1 tergolong sangat baik. Kualitas telur ayam IPB D-1 G7 sangat baik.

\section{DAFTAR PUSTAKA}

Becker, W. A. 1985. Manual of Quantitative Genetics. 3rd Ed. Pullman, Washington (US): Washington State University.

BPS (Badan Pusat Statistik). 2019. Statistik Indonesia 2019. Jakarta (ID): Badan Pusat Statistik.

Darwati, S., R. Afnan, H. Nurcahya, \& N. Widayanti. 2019. Produksi telur dan reproduksi ayam silangan antara ayam merawang dengan ayam arab serta pendugaan nilai ripitabilitasnya. J. Pet. Indonesia. 21(2): 102-108.

Dirjen PKH (Direktorat Jenderal Peternakan dan Kesehatan Hewan). 2018. Statistik Kesehatan peternakan dan Kesehatan Hewan 2018. Jakarta (ID): Dirjen PKH

Creswell, D. C., \& B. Gunawan. 1982. Pertumbuhan badan dan produksi telur dari 5 strain ayam sayur pada sistem peternakan intensif. Pros. Seminar Penelitian Peternakan, Bogor.
Hartono, T. A., A. W. Puger, I. M. Nuriyasa. 2014. Kualitas telur lima jenis ayam kampung yang memiliki warna bulu berbeda. Peternakan Tropika. 2(2): 153162.

Lasley, J. F. 1987. Genetics of Livestock Improvement. New Dehli (IN): Prentice Hall of India.

Mattjik, A. A., \& I. M. Sumertajaya. 2000. Perancangan percobaan dengan aplikasi SAS dan minitab. Bogor (ID): IPB Pr.

Mountney, G. I. 1976. Poultry Technology 2nd Ed. Wesport (US). The Avi Publishing Inc.

Noor, R. R. 2008. Genetika Ternak. Bogor (ID): Penebar Swadaya.

SNI (Standar Nasional Indonesia). 2008. Telur Ayam Konsumsi SNI-3926:2008. Jakarta (ID): Badan Standarisasi Nasional.

Stadelman, W. J., \& O. J. Cotteriil. 1977. Egg Science and Technology. 2nd Ed. Wetsport (US): The Avi Publishing Inc.

Widyantara, P. R. A., G. A. M. Kristina Dewi, \& I. N. T. Ariana. 2017. Pengaruh lama penyimpanan terhadap kualitas telur konsumsi ayam kampung dan ayam lohman brown. Majalah Ilmiah Pet. 20(1): 5-11. 